Jurnal Keuangan dan Perbankan, Vol.20, No.1 Januari 2016, hlm. 127-140

Terakreditasi SK. No. 040/P/2014

http://jurkubank.wordpress.com

\title{
PERBANDINGAN KUALITAS LAYANAN BANK SYARIAH DAN BANK KONVENSIONAL (Pendekatan Model PBZ)
}

\author{
H. Abdul Choliq \\ Jurusan M anajemen Dakwah Fakultas Dakwah dan Komuniasi UIN Walisongo \\ JI. Raya Semarang - Batang, Ngaliyan, Kota Semarang, Jawa Tengah 50185 \\ Irwan Misbach \\ Jurusan M anajemen Dakwah Fakultas Dakwah dan Komuniasi UIN Alauddin \\ J. H. Yasin Limpo - Gowa, Sulawesi Selatan 92113
}

\begin{abstract}
The purpose of this study was to determine differences in the customers perception of the service quality of Islamic banks and conventional bank. This is donebecausethe Islamic bank (shari'a) is a bank that is operationally different from conventional banks although in some instances. They have similarities, especially in the technical side. This study measured differences in theservices quality provided by Islamic banks and conventional banks in $M$ akassar. The number of respondents are 200 people with accidental sampling method. Testing the hypothesis in this study used a comparativetest of independent t-test (independent samples). The results of this study wereno significant differ ence between the servicequal ity I slamic banks with conventional banks. Thestudy al so only measures customer perceptions about the service quality of the bank are per ceived and not to measuretheir perceptions of theservicequality of expected, so it cannot beproven levels of customer satisfaction.
\end{abstract}

Keywords: Service Q uality, Islamic Banks, Conventional Banks

Perubahan permintaan konsumen, peningkatan harapan untuk memperoleh kualitas produk maupun layanan yang unggul dan adanya kompetisi global menciptakan lingkungan yang kompetitif di berbagai sektor industri yang berbeda. Kualitasmerupakan suatu icon untuk konsumen ketika menyeleksi layanan atau produk dan di saat yang sama perusahaan berusaha untuk menyediakan kualitas layanan atau produk yang sesuai dengan kebutuhan dan keinginan konsumen (Irfan dan Ijaz, 2011). Kualitas telah menjadi penentu utama di kedua sektor industri dan jasa untuk mendapatkan

Korespondensi dengan Penulis:

Irwan Misbach: Telp. +62 8529962 4579; Fax. +62 4118221400

E-mail: irwan.misbach@uin-alauddin.ac.id 
imbalan yang maksimum atas investasi dan juga memberikan kontribusi dalam pengurangan biaya (Parasuraman, Berry dan Zeithaml, 1985). Kualitas telah dianggap sebagai keuntungan strategis bagi organisasi untuk mendapatkan kesuksesan dan bertahan dalam dunia bisnis.

Yavas, Bankenstein dan Stuhldreier (2004) menemukan bahwa kualitas layanan adalah akar dari kepuasan pelanggan pada bank ritel di Jerman. Mengi (2009) menyatakan bahwa layanan pelanggan merupakan bagian integral dari setiap segi perbankan dan menentukan masa depan dari setiap organisasi perbankan. Hal ini seperti yang dikemukakan oleh Kotler (1997) bahwa kebanyakan pelanggan tidak lagi bersedia menerima dan mentoleransi kinerja kualitas yang biasa saja.

Sektor manufaktur di banyak negara di seluruh dunia telah berhasil diuntungkan dengan menerapkan prinsip-prinsip manajemen mutu dan memperoleh sukses yang luar biasa baik di pasar lokal maupun di pasar global. Produk yang nyata dalam sifat dan kualitas dari produk dapat dengan mudah diukur sedangkan jasa tidak berwujud dan sulit diukur dibandingkan dengan produk. Karena tidak berwujud, sulit untuk mengukur kualitas layanan apapun karena sangat tergantung pada persepsi dan harapan pelanggan (Samson \& Parker, 1994).

Konseptualisasi awal kualitas layanan didasarkan pada paradigma diskonfirmasi yang digunakan dalam literatur jenis barang fisik (Misbach, 2012: 88). Paradigma diskonfirmasi ini merupakan dasar bagi Parasuraman, Berry dan Zeithaml (1985) yang memperkenalkan model SERVQUAL (Service Quality), yang memandang kualitas Iayanan sebagai kesenjangan antara tingkat layanan yang diharapkan dengan tingkat persepsi konsumen dari layanan yang diterima. Hasil penelitian Parasuraman et al. (1985) memperbaiki pencapaian kualitas dalam layanan telah menjadi perhatian penting dari tahun 1980-an, dengan eksplorasi kualitas layanan dalam empat bisnis jasa (perbank- an ritel, kartu kredit, broker sekuritas, perbaikan dan pemeliharaan produk). Parasuraman et al. (1988) mengembangkan penelitiannya yang menghasilkan 22 instrumen skala pengukuran persepsi konsumen yang dikenal dengan model SERVQUAL (kualitaslayanan). Model pengukuran SERVQUAL ini dikenal dengan 5 dimensi : realibility (keandalan), responsiveness (daya tanggap), assurance (jaminan), empathy (empati), dan tangible (bukti fisik), untuk menilai persepsi kualitas layanan konsumen dalam organisasi jasa dan ritel.

Penggunaan dimensi SERVQUAL di lintas industri harus disesuaikan dengan karakteristik industri yang akan diteliti karena adanya tipe/ konsep layanan yang berbeda pada masing-masing industri (Wirat, 2007). Hal ini sesuai dengan Babakus dan Boller (1992, dalam Wirat, 2007) bahwa SERVQUAL tergantung konteks jasa tertentu yang bersifat murni penjual jasa seperti bank, jasa telepon, broker, reparasi peralatan, asuransi, rumah sakit ataupun perusahaan kartu kredit.

Perbankan merupakan lembaga keuangan yang menyediakan jasa keuangan. Dalam perkembangannya, kegiatan operasional perbankan bukan hanya menghimpun dan menyalurkan dana saja tetapi juga menjadikan kualitas Iayanan sebagai strategy based dalam rangka memenangkan persaingan. Dalam lingkungan perbankan yang kompetitif saat ini, sebagian besar bank-bank menawarkan produk yang sama atau serupa di seluruh dunia dan kualitas layanan adalah penting artinya untuk membedakan diri mereka di pasar (H ossain dan Leo, 2009). Di Indonesia, sistem perbankan menganut dual banking system, sehingga nasabah masih dapat melakukan pilihan antara bank konvensional dengan bank syariah.

Di semua industri jasa, isu kualitas layanan tetap menjadi kritis sebagai bisnis untuk mempertahankan keunggulan komparatif di pasar. Demikian juga dalam jasa keuangan, khususnya perbankan, bersaing di pasar dengan produk yang tidak dibedakan secara umum, kualitas Iayanan 


\section{Perbandingan Kualitas Layanan Bank Syariah Dan BankKonvensional (Pendekatan Model PBZ)}

H. Abdul Choliq \& Irwan Misbach

yang kompetitif menjadi senjata utama. Meningkatkan kualitas layanan dalam rangka untuk mencapai dan mempertahankan keunggulan kompetitif adalah penting untuk mengidentifikasi karakteristik kualitas layanan tersebut yang dianggap penting oleh pelanggan.

\section{Kualitas Layanan}

Menurut Cronin dan Taylor (1992), harapan untuk kualitas layanan tinggi telah meningkat dalam kehidupan masyarakat akibat peningkatan ekonomi pada sektor jasa di hampir semua negara di dunia. Pelanggan memainkan peran penting dalam keberhasilan atau kegagalan dari suatu layanan atau produk yang merupakan persepsi mereka ketika menilai kualitas layanan atau produk tertentu. Oleh karena itu, memberikan kualitas layanan unggul kepada pelanggan adalah strategi kunci yang diadopsi oleh sebagian besar organisasi untuk mempertahankan dalam lingkungan yang kompetitif (Parasuraman etal, 1985) dan ini mendapatkan perhatian yang cukup besar dari para peneliti di seluruh dunia (Nimit dan Monica, 2007). Oleh karena itu, kelangsungan hidup dari setiap organisasi di lingkungan yang sangat kompetitif ini tergantung pada pemberian kualitas Iayanan yang unggul kepada pelanggan mereka.

Kualitas layanan mendapat perhatian dan kepentingan kedua praktisi dan peneliti selama beberapa dekade terakhir dalam literatur kualitas layanan (Wisniewski 2001, Nimit dan Monika, 2007). Kualitas Iayanan dikonseptualisasikan sebagai persepsi konsumen tentang tingkat layanan baik itu adalah kualitas tinggi atau kualitas rendah (Zeithaml et al., 1990). Umumnya, kualitas layanan diasumsikan perbedaan persepsi antara harapan pelanggan dan yang terima atau atau tidak diterima oleh pelanggan (Gronroos, 2001; Parasuraman et al, 1988). Meskipun kualitas layanan merupakan topik diskusi baik oleh akademisi dan peneliti selama beberapa dekadeterakhir, tetapi belum ada definisi yang komprehensif (Wisniewski, 2001). Namun, kualitas layanan dapat dilihat sebagai:

1. Ini adalah perbedaan antara harapan dan persepsi pelanggan, harapan berarti kinerja penyedialayanan selama memberikan layanan sedangkan persepsi adalah pengukuran kualitas layanan oleh penyedia layanan (Parasuraman et al, 1985, 1988.).

2. Menurut Asubonteng et al. (1996, p-24): Kualitas layanan dapat didefinisikan sebagai "perbedaan antara harapan pelanggan mengenai kinerja layanan sebelum layanan diterima dan persepsi mereka terhadap layanan yang diterima".

3. Menurut Gefan (2002), itu adalah perbandingan yang dibuat oleh pelanggan antara kualitas layanan yang mereka ingin terima dan apa yang mereka benar-benar diterima dari penyedia Iayanan. Oleh karena itu, kualitas layanan adalah keputusan dan konsekuensi dari konsumen setelah melakukan perbandingan dari harapan dengan persepsi layanan yang sebenarnya diterima oleh organisasi jasa (Gronoors, 1984; Parasuraman et al., 1985, 1988) dan setiap kekurangan atau selisih yang terjadi direpresentasikan sebagai sebuah gap (kesenjangan).

Berbagai model telah dikembangkan untuk mengukur persepsi kualitas Iayanan (Grönroos 1984; Parasuraman et al., 1988, 1991; Bahia \& Nantel, 2000; A Idlaigan \& Buttle, 2002; Hossain \& Leo, 2009). Parasuraman etal. (1988) mengusulkan membangun lima dimensi persepsi kualitas layanan, yaitu tangible, kehandalan, responsive, jaminan dan empati dengan item yang mencerminkan persepsi harapan dan kinerja.

Dimensi kualitas layanan bank membedakan antara pelanggan dalam hal hubungan persepsi kualitas layanan dan kepuasan pelanggan (Jabnoun \& Khalifa, 2005; N dubisi \& Wah, 2005; Spathis et 
al, 2004; Stafford, 1996). Kualitas dipandang sebagai pembeda strategis kunci dalam sektor jasa keuangan, dengan sebagian besar pemain utama melakukan beberapa bentuk inisiatif kualitas (GalIoway dan Blanchard, 1996). Beberapa atribut (seperti service, kehandalan dan kualitas yang dirasakan pelanggan) telah dipertimbangkan dalam model yang terkenal yaitu model Servqual, dapat dianggap sebagai faktor penting dalam menentukan kualitas layanan bank (Jun dan Cai, 2001).

Banyak penelitian dilakukan oleh para pakar di bidang manajemen jasa untuk mengetahui secara rinci dimensi kualitas layanan yang mempengaruhi kualitas layanan, termasuk menentukan dimensi yang paling menentukan dalam kualitas jasa tersebut (Jasfar, 2005)

Berdasarkan penelusuran literatur, konseptualisasi tentang kualitas layanan mengalami perkembangan yang sangat pesat sejak tahun 1980. Dimulai dengan konseptualisasi Gronroos (1984) yang dinamakan sebagai "the N ordic M odel", yaitu sebagai berikut:

1. Konsep pertama, tentang kualitas Iayanan ini mengusulkan konsep dua dimensi, yaitu technical quality dan functional quality. Pengertian kualitas teknik adalah apa yang didapat oleh pelanggan, sedangkan kualitas fungsional berarti bagaimana penerimaan dari pelanggan mengenai kualitas. Pengukuran kualitasadalah dengan memperbandingkan antara expected service dan perceived service.

2. Konsep kedua, dikemukakan oleh Rust dan Oliver (1994) dalam Brady dan Cronin (2001) dengan konsep tiga dimensi, yaitu serviceproduct, service delivery dan service environment. Lebih lanjut mereka memandang bahwa persepsi keseluruhan dari kualitas layanan berdasarkan evaluasi pengguna layanan terhadap tiga dimensi tersebut, yang meliputi:

a. Interaksi pelanggan dengan pekerja (functional quality) (Gronroos, 1984) b. Lingkungan jasa tempat berlangsungnya pertukaran jasa, dan

c. Bentuk jasa itu sendiri atau outcome yang diterima oleh pengguna jasa.

3. Konsep ketiga, dikemukakan oleh Parasuraman et al., (1985) yang kemudian direvisi pada tahun 1988 menggunakan paradigm disconfirmation dan mendukung konsep Gronross (1984). Berdasarkan konsep ini, kualitas layanan merupakan selisih antara nilai yang diterima dengan nilai yang diharapkan padalima dimensi: tangibles, reliability, responsiveness, assurance dan empathy. Konsep ini walaupun mengundang banyak kritik namun banyak pula pendukungnya.

4. Konsep keempat, yang dikemukakan oleh Dabholkar et al., (1996) mengusulkan bahwa kualitas Iayanan merupakan konstruk multidimensi dan multilevel. Konsep ini melahirkan konsep pengukuran kualitas layanan berdasarkan dimensi dan subdimensi. Walaupun konsep ini mendapat banyak dukungan, namun permasalahan yang muncul adalah bagaimana menentukan faktor-faktor atau subdimensi yang mendasarinya. Dabholkar et al., (1996) secara hati-hati, tidak ingin membuat general isasi hasil penelitiannya, tetapi menyebutkan bahwa konseptualisasi kualitas layanan yang dikemukakannya berlaku untuk bidang perdagangan ritel.

Peneliti dan akademisi kualitas telah menyadari kebutuhan untuk mengembangkan langkahlangkah yang valid dan berbeda dari SQ dalam beberapa dekade terakhir (Bahia dan N antel, 2000; Othman dan Owen, 2001).

\section{Skala SERVQUAL - PBZ}

Pengukuran kualitas layanan merupakan isu kritis dan beberapa model kualitas layanan yang disajikan selama beberapa dekade terakhir, tetapi 


\section{Perbandingan Kualitas Layanan Bank Syariah Dan BankKonvensional (Pendekatan Model PBZ)}

H. Abdul Choliq \& Irwan Misbach

yang paling umum digunakan adalah 'SERVQUAL' oleh Parasuraman, Zeithmal dan Berry (1985). Menurut Parasuraman et al . (1985), persepsi pelanggan tentang kualitas layanan dapat ditentukan oleh lima 'Gap'. The 'SERVQUAL' skala didasarkan pada gap 5 dan sepuluh dimensi asli yang disempurnakan menjadi lima dimensi dan 22 item (Parasuraman et al., 1988).

Skala SERVQUAL (Parasuraman et al., 1985, $1988,1991)$ telah banyak dimanfaatkan oleh manajer dan akademisi (Irfan dan Ijaz, 2011). Popularitas SERVQUAL adalah karena sejumlah keuntungan yang telah diakui untuk (Buttle, 1994):

1. Hal ini diterima sebagai standar untuk menilai dimensi yang berbeda dari kualitas layanan.

2. Telah terbukti berlaku untuk sejumlah situasi layanan.

3. Ini telah terbukti dapat diandalkan, yang berarti bahwa pembaca yang berbeda menafsirkan pertanyaan-pertanyaan yang sama.

4. Instrumen ini pelit dalam hal ini memiliki sejumlah item. ini berarti bahwa pelanggan dan karyawan dapat mengisinya dengan cepat.

5. Memiliki prosedur analisis standar untuk membantu interpretasi hasil.

Parasuraman, Zeithaml dan Berry (1985) melakukan serangkaian penelitian khususterhadap beberapa jenis industri jasa dan berhasil mengidentifikasi 10 faktor utama yang menentukan kualitas layanan yaitu Reliabilitas, Responsivitas atau daya tanggap, Kompetensi, A kses, Kesopanan (courtesy), Komunikasi, Kredibilitas, Keamanan (security), Kemampuan memahami pelanggan, Bukti fisik (tangibles).

Dalam riset selanjutnya, Parasuraman, Zeithaml dan Berry (1988) kembali melakukan penelitian pada kelompok fokus (focus group), baik pengguna maupun penyedia layanan, dan menemukan adanya over lapping di antara beberapa dimensi di atas. mereka menemukan bahwa terdapat hubungan yang sangat kuat antara communication, competence, coutesy, credibility dan security yang kemudian dikelompokkan menjadi satu dimensi yaitu assurance. Hubungan yang sangat kuat juga terjadi pada access dan understanding yang kemudian dikelompokkan menjadi emphaty. Oleh sebab itu, mereka menyederhanakan sepuluh dimensi tersebut menjadi lima dimensi pokok kualitas layanan. Kelima dimensi tersebut disusun sesuai urutan tingkat kepentingan relatifnya sebagai berikut:

a. Reliability (kehandalan) berkaitan dengan kemampuan perusahaan untuk memberikan layanan yang akurat sejak pertama kali tanpa membuat kesalahan apapun dan menyampaikan jasanya sesuai dengan waktu yang disepakati dan dapat dipercaya;

b. Responsiveness (daya tanggap) berkenaan dengan kesediaan dan kemampuan para karyawan untuk membantu para pelanggan dan merespons permintaan mereka, serta menginformasikan kapan jasa akan diberikan secara cepat dan tanggap, misal nya kesigapan karyawan dal am melayani pelanggan, kecepatan karyawan dalam menangani transaksi, dan penangan keluhan pelanggan;

c. A ssurance (jaminan) yakni perilaku para karyawan mampu menumbuhkan kepercayaan pelanggan terhadap perusahaan dan perusahaan bisa menciptakan rasa aman bagi para pelanggannya. Jaminan juga berarti bahwa para karyawan selalu bersikap sopan dan menguasai pengetahuan dan keterampilan yang dibutuhkan untuk menangani setiap pertanyaan atau masalah pelanggan, meliputi ke mampuan karyawan atas: pengetahuan terhadap produk secara tepat, kualitas keramahtamahan, perhatian dan kesopanan dalam member pelayanan, keterampilan dalam memberikan informasi, kemampuan dalam memberikan rasa keamanan di dalam memanfaatkan jasa yang ditawarkan, dan kemampuan 
dalam menanamkan kepercayaan pelanggan terhadap perusahaan. Dimensi kepastian atau jaminan ini merupakan gabungan dari dimensi: 1. Kompetensi (competence), artinya keterampilan dan pengetahuan yang dimiliki oleh para karyawan untuk melakukan pelayanan, 2. Kesopanan (courtesy), yang meliputi keramahan, perhatian dan sikap para karyawan, 3. Kredibilitas (credibility), meliputi hal-hal yang berhubungan dengan kepercayaan kepada perusahaan, seperti reputasi, prestasi dan sebagainya.;

d. Emphaty (empati) yaitu perhatian secara individual yang diberikan perusahaan kepada pelanggan seperti kemudahan untuk menghubungi perusahaan, kemampuan karyawan dan perusahaan dalam memberikan perhatian tulus dan bersifat individual atau memahami masalah pelanggan dan bertindak demi keinginan dan kebutuhan pelanggan. Dimensi empati ini merupakan gabungan dari dimensi: 1. Akses (access), meliputi kemudahan untuk memanfaatkan jasa yang ditawarkan perusahaan, 2. Komunikasi (communication), merupakan kemampuan melakukan komunikasi untuk menyampaikan informasi kepada pelanggan atau memperoleh masukan dari pelanggan, 3. Pemahaman pada Pelanggan (understanding the customer), meliputi usaha perusahaan untuk mengetahui dan memahami kebutuhan dan keinginan pelanggan;

e. Tangible (bukti fisik) yaitu kemampuan perusahaan untuk menunjukkan eksistensinya kepada pihak eksternal yang meliputi penampilan fasilitas fisik (gedung, ruang front office, tersedianya tempat parkir, kebersihan, kerapihan dan kenyamanan ruangan dan lain-lain), perlengkapan dan peralatan komunikasi (teknologi) serta penampilan karyawannya.

Penggunaan dimensi SERVQUAL ini harus disesuaikan dengan karakteristik industri yang akan diteliti karena adanya tipe/ konsep pelayanan yang berbeda pada masing-masing industri (Wirat, 2007). Hal ini sesuai dengan Babakus dan Boller (1992, dalam Wirat, 2007) bahwa dimensi SERVQUAL tergantung pada konteks jasa tertentu yang bersifat murni penjual jasa seperti bank, jasa telepon, broker, reparasi peralatan, asuransi, rumah sakit ataupun perusahaan kartu kredit. Bahkan determinan kualitas layanan untuk tipe industri yang sama bisa bervariasi menurut konteks riset yang dilakukan (Joseph, 1998 \& Hampton, 1993 dalam Tjiptono \& Chandra, 2005).

Kualitas layanan dipandang sebagai isu penting dalam industri perbankan (Stafford, 1996) dan dalam beberapa tahun terakhir, telah dilakukan sejumlah studi yang berusaha untuk mengembangkan instrumen kualitas pelayanan bagi bank. Mayoritas peneliti telah menggunakan SERVQUAL sebagai titik awal, mengubah dan atau menambahkan item untuk mencerminkan lokasi dan perbedaan organisasi (Othman dan Owen, 2001; Jabnoun dan Khalifa, 2005; A bdullah et al., 2011)

\section{Perbedaan Bank Syariah dan Bank Konvensional}

Tidak sedikit masyarakat umum dan bahkan kalangan intelektual terdidik yang belum memahami konsep bank syariah. Mereka beranggapan bagi hasil adalah sama dengan bunga. Mereka mengklaim, bahwa bagi hasil hanyalah nama lain dari sistem bunga. Pandangan ini juga masih terdapat di kalangan sebagian kecil ustadz yang belum memahami konsep dan operasional bagi hasil.

Bank Islam (syariah) merupakan bank yang secara operasional berbeda dengan bank konvensional. Dalam beberapa hal, bank syariah dan bank konvensional memiliki persamaan terutama dalam sisi teknis. A kan tetapi terdapat banyak perbedaan yang mendasar diantara keduanya yang menyangkut akad dan asek legalitas, lembaga penyel esaian sengketa, usaha yang dibiayai dan lingkungan kerja serta coorporate culture (Misbach, 2013: 66). 


\section{Perbandingan Kualitas Layanan Bank Syariah Dan Bank Konvensional (Pendekatan Model PBZ)}

H. Abdul Choliq \& Irwan Misbach

Pengertian bank menurut Undang-Undang No. 10 tahun 1999 tentang perubahan atas UndangUndang N o. 7 tahun 1992 tentang perbankan adaIah badan usaha yang menghimpun dana dari masyarakat dal am bentuk simpanan dan menyalurkannya kepada masyarakat dalam bentuk kredit dan/ atau bentuk-bentuk lainnya dalam rangka meningkatkan taraf hidup rakyat banyak.

Bank konvensional dapat didefinisikan seperti pada pengertian bank umum pada pasal 1 ayat 3 Undang-Undang N o. 10 tahun 1998 dengan menghilangkan kalimat "dan atau berdasarkan prinsip syariah", yaitu bank yang melaksanakan kegiatan usaha secara konvensional yang dalam kegiatannya memberikan jasa dalam Ialu lintas pembayaran.

Perbedaan antara bank syariah dan bank konvensional disajikan dalam Tabel 1 berikut (Murni, 2009).

Bank Islam atau selanjutnya disebut dengan Bank Syariah, adalah bank yang beroperasi dengan tidak mengandalkan pada bunga. Perbankan syariah adalah segala sesuatu yang menyangkut tentang bank syariah dan unit usaha syariah, men- cakup kelembagaan, kegiatan usaha, serta cara dan proses dalam melaksanakan kegiatan usahanya. Menurut Antonio dan Perwataatmadja yang dikutip oleh Ismail (2011: 32) dalam buku Perbankan Syariah Bank Islam adalah bank yang beroperasi dengan prinsip syariah Islam dan bank yang tata cara beroperasinya mengacu kepada ketentuanketentuan al-Qur'an dan al-Hadits.

Dalam penelitian ini, tidak mengukur tingkat kepuasan pelanggan yang diukur berdasarkan kualitas layanan Parasuraman et al . (1988), tapi pendekatannya pada model atau dimensi kualitas layanannya saja. Sedang kualitas layanan diukur berdasarkan studi yang dilakukan oleh Cronin dan Taylor (1992) yang merupakan versi terkini yang merupakan modifikasi dari model SERVQUAL Parasuraman et al. (1988) yang mengeluarkan nilai harapan secara keseluruhan.

Berdasarkan pemahaman teoritis tersebut, dapat disusun suatu kerangka pemikiran (logical framew ork) yang dapat dijadikan acuan dalam melakukan suatu penelitian tentang kualitas Iayanan pada industri perbankan, seperti yang terlihat pada Gambar 1 berikut.

Tabel 1. Perbedaan Bank Syariah dan Bank Konvensional

\begin{tabular}{|c|c|}
\hline Bank Syariah & Bank Konvensional \\
\hline Melakukan investasi yang halal saja & Investasi yang halal dan haram \\
\hline Berdasarkan prinsip bagi hasil & Memakai perangkat bunga \\
\hline $\begin{array}{l}\text { Besarnya disepakati pada waktu akad dengan berpedoman } \\
\text { kepada kemungkinan untung rugi }\end{array}$ & $\begin{array}{l}\text { Besarnya disepakati pada waktu akad dengan asumsi } \\
\text { akan selal u untung }\end{array}$ \\
\hline $\begin{array}{l}\text { Besar rasio didasarkan pada jumlah keuntungan yang } \\
\text { diperoleh }\end{array}$ & $\begin{array}{l}\text { Besarny presentase didasarkan pada jumlah modal } \\
\text { yang dipinjamkan }\end{array}$ \\
\hline Rasio tidak berubah selama akad masih berlaku & Bunga dapat mengambang dan besarnya naik turun \\
\hline Kerugian ditanggung bersama & $\begin{array}{l}\text { Pembayaran bunga besarnya tetap tanpa pertimbangan } \\
\text { untung rugi }\end{array}$ \\
\hline $\begin{array}{l}\text { Jumlah pembagian laba meningkat sesuai dengan } \\
\text { peningkatan keuntungan }\end{array}$ & $\begin{array}{l}\text { Jumlah bunga tidak meningkat sekalipun keuntungan } \\
\text { meningkat }\end{array}$ \\
\hline Eksistensi tidak ada yang meragukan keabsahan bagi hasil & Eksistensi bunga diragukan \\
\hline $\begin{array}{l}\text { Berorientasi pada keuntungan (profit oriented) dan } \\
\text { kemakmuran dan kebahagian dunia akhirat }\end{array}$ & Profit oriented \\
\hline $\begin{array}{l}\text { Hubungan dengan nasabah dalam bentuk hubungan } \\
\text { kemitraan }\end{array}$ & $\begin{array}{l}\text { Hubungan dengan nasabah dalam bentuk hubungan } \\
\text { kreditur-debitur }\end{array}$ \\
\hline $\begin{array}{l}\text { Penghimpunan dan penyaluran dana harus sesuai dengan } \\
\text { fatwa Dewan Pengawas Syariah }\end{array}$ & Tidak terdapat dewan sejenis \\
\hline
\end{tabular}

Sumber: Murni, 2009 


\section{Jurnal Keuangan dan Perbankan | PERBANKAN}

Vol. 20, N o.1, Januari 2016: 127-140

\section{METODE}

Jenis penelitian yang digunakan adalah penelitian kuantitatif dengan Statistik deskriptif. Penelitian ini mengukur perbedaan kualitas layanan yang diberikan oleh bank syariah dan bank konvensional di Makassar. Tempat penelitian ini adalah bank syariah yang terdiri dari Bank Muamalat Indonesia, Bank Syariah M andiri, Bank BRI Syariah, Bank Mega Syariah, Bank BN I Syariah, dan Bank Syariah Bukopin dan bank konvensional seperti Bank BCA, Bank BRI, Bank BNI, Bank Mandiri dan Bank M ega yang memiliki kantor cabang di Makassar.

Pengambilan sampel dilakukan dengan metode accidental sampling. Karakteristik responden dalam penelitian ini yaitu nasabah bank yang telah merasakan dan menikmati layanan bank, baik sebagai nasabah bank syariah atau nasabah bank konvensional. Pengumpulan data pada penelitian ini dilakukan dengan metode survey. Instrumen yang digunakan untuk mengumpulkan data dalam penelitian ini adalah kuesioner yang berupa daftar pertanyaan tertulis, dimana responden diminta untuk menjawab atau mengisi beberapa hal yang berkenaan dengan identitas mereka dan memberi tanggapan terhadap indikator-indikator dari dimensi kualitaslayanan menurut persepsi mereka.
Penyebaran kuesioner dilakukan secara pribadi, yaitu memberikan kuesioner secara langsung kepada responden, dengan menggunakan skala Likert 5 point: 1 =Sangat Tidak Penting, $2=$ Tidak Penting, $3=$ Cukup penting, $4=$ Penting, $5=$ Sangat Penting untuk penilaian tingkat kepentingan/ harapan, sedang penilaian tingkat kinerja/ pelaksanaan layanan bank menggunakan skala Likert 5 poin: 1 = Sangat Tidak Setuju, $2=$ Tidak Setuju, $3=$ Cukup Setuju, $4=$ Setuju dan $5=$ Sangat Setuju.

Untuk menentukan ukuran sampel penelitian dari populasi yang tidak terbatas ini digunakan rumus 15 atau 20 kali variabel bebas (Hair, et al., 2006), jadi didapat hasil sebagai berikut: $20 \times 5$ (jumlah variabel bebas) $=100 \times 2$ Bank $=200$

Penelitian ini menggunakan sampel sebesar 200 sampel yang berasal dari 100 responden bank syariah dan 100 responden bank konvensional.

A nal isis data dalam penelitian ini adalah Uji beda rata-rata sampel bebas (independent sample) digunakan untuk menguji perbedaan rata-rata dua sampel bebas (independent) atau sampel tidak berhubungan, dalam hal ini sampel nasabah bank syariah dengan sampel nasabah bank konvensional. Pengujian hipotesis beda rata-rata dua sampel bebas, uji statistiknya menggunakan distribusi $\mathrm{t}(\mathrm{Uji} \mathrm{t})$, dengan rumus:

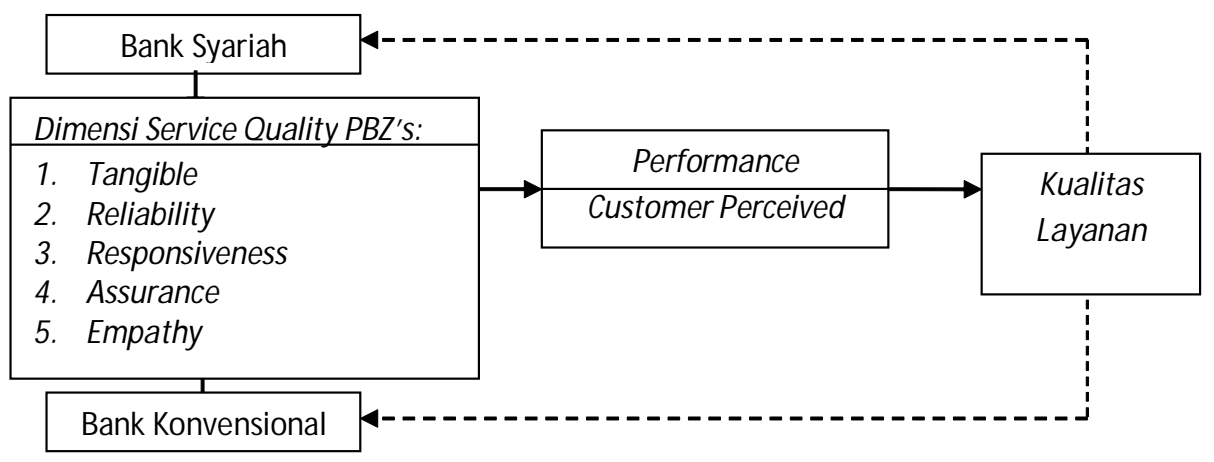

Gambar 1. Kualitas Layanan M odel PBZ 


\section{Perbandingan Kualitas Layanan Bank Syariah Dan BankKonvensional (Pendekatan Model PBZ)}

H. Abdul Choliq \& Irwan Misbach

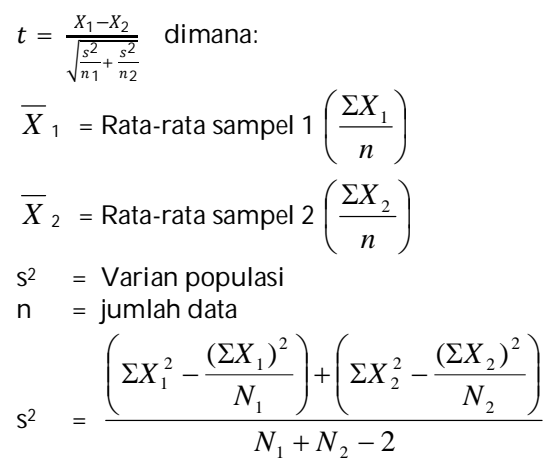

\section{HASIL \\ Kualitas Layanan Bank Syariah}

Kualitas Iayanan Parasuraman et al. (1988) terdiri dari 22 indikator yang terdiri dari 5 variabel atau lebih dikenal dengan 5 dimensi yaitu bukti fisik, kehandalan, daya tanggap, jaminan dan empati. Hasil statistik deskripsi kualitas Iayanan bank syariah ditunjukkan pada Tabel 3 di bawah ini.

Tabel 2. Kualitas Layanan Bank Syariah

\begin{tabular}{|llccc|}
\hline Variabel/Indikator & N & M inimum & M aximum & M ean \\
\hline Peralatan Modern & 100 & 2 & 5 & 3.69 \\
Fasilitas Menarik & 100 & 2 & 5 & 3.85 \\
Penampilan Karyawan Menarik & 100 & 3 & 5 & 3.95 \\
Brosur \& Dokumen Lain Menarik & 100 & 2 & 5 & 3.77 \\
\hline Bukti Fisik & $\mathbf{1 0 0}$ & $\mathbf{3}$ & $\mathbf{5}$ & $\mathbf{3 . 9 0}$ \\
\hline Layanan sesuai yang Dijanjikan & 100 & 2 & 5 & 4.01 \\
Diandalkan Menangani Masalah & 100 & 3 & 5 & 4.19 \\
Layanan yang Diberikan Tepat & 100 & 2 & 5 & 3.96 \\
Kepastian Waktu Layanan & 100 & 2 & 5 & 3.93 \\
Minim Kesalahan Pencatatan & 100 & 2 & 5 & 3.86 \\
\hline Kehandalan & $\mathbf{1 0 0}$ & $\mathbf{2}$ & $\mathbf{5}$ & $\mathbf{4 . 0 0}$ \\
\hline Waktu Layanan yang Cepat & 100 & 2 & 5 & 3.92 \\
Memberikan Layanan dengan Segera & 100 & 2 & 5 & 3.87 \\
Kesediaan Membantu & 100 & 1 & 5 & 4.02 \\
Respon sesuai Keinginan Nasabah & 100 & 2 & 5 & 3.99 \\
\hline Daya Tanggap & $\mathbf{1 0 0}$ & $\mathbf{2}$ & $\mathbf{5}$ & $\mathbf{4 . 0 4}$ \\
\hline Rasa Percaya & 100 & 2 & 5 & 3.90 \\
Rasa Aman & 100 & 1 & 5 & 3.90 \\
Konsisten & 100 & 3 & 5.00 \\
Profesionalisme Karyawan & 100 & 2 & 5.91 \\
\hline Jaminan & $\mathbf{1 0 0}$ & $\mathbf{2}$ & $\mathbf{5}$ & 3.97 \\
\hline Perhatian Individu & 100 & 2 & 5 & 3.84 \\
Jam Kerja Nyaman & 100 & 1 & 5 & 3.69 \\
Perhatian Karyawan & 100 & 2 & 5 & 3.72 \\
Rasa Ketertarikan & 100 & 2 & 5.84 \\
Pemahaman Kebutuhan & 100 & 3 & $\mathbf{5}$ & $\mathbf{3 . 8 7}$ \\
\hline Empati & $\mathbf{1 0 0}$ & $\mathbf{2}$ & & \\
\hline
\end{tabular}

Sumber: Data diolah, 2015 
Tabel 3. Kualitas Layanan Bank Konvensional

\begin{tabular}{|llccc|}
\hline Variabel/Indikator & N & Minimum & Maximum & M ean \\
\hline Peralatan M odern & 100 & 2 & 5 & 3.53 \\
Fasilitas Menarik & 100 & 1 & 5 & 3.65 \\
Penampilan Karyawan Menarik & 100 & 2 & 5 & 4.01 \\
Brosur \& Dokumen Lain Menarik & 100 & 2 & 5 & 3.88 \\
\hline Bukti Fisik & $\mathbf{1 0 0}$ & $\mathbf{3}$ & $\mathbf{5}$ & $\mathbf{3 . 9 3}$ \\
\hline Layanan sesuai yang Dijanjikan & 100 & 2 & 5 & 3.79 \\
Diandalkan Menangani Masal ah & 100 & 3 & 5 & 4.24 \\
Layanan yang Diberikan Tepat & 100 & 2 & 5 & 3.82 \\
Kepastian Waktu Layanan & 100 & 2 & 5 & 3.83 \\
Minim Kesalahan Pencatatan & 100 & 2 & 5 & 3.73 \\
\hline Kehandalan & $\mathbf{1 0 0}$ & $\mathbf{3}$ & $\mathbf{5}$ & $\mathbf{3 . 9 0}$ \\
\hline Waktu Layanan yang Cepat & 100 & 2 & 5 & 3.70 \\
Memberikan Layanan dengan Segera & 100 & 2 & 5 & 3.81 \\
Kesediaan Membantu & 100 & 2 & 5 & 3.92 \\
Respon sesuai Keinginan Nasabah & 100 & 3 & 5 & 3.87 \\
\hline Daya Tanggap & $\mathbf{1 0 0}$ & $\mathbf{3}$ & $\mathbf{5}$ & $\mathbf{3 . 9 2}$ \\
\hline Rasa Percaya & 100 & 2 & 5 & 3.98 \\
Rasa Aman & 100 & 2 & 5 & 3.90 \\
Konsisten & 100 & 3 & 5 & 3.83 \\
Profesionalisme Karyawan & 100 & 2 & 5 & 3.69 \\
\hline Jaminan & $\mathbf{1 0 0}$ & $\mathbf{3}$ & $\mathbf{5}$ & $\mathbf{3 . 9 5}$ \\
\hline Perhatian Individu & 100 & 2 & 5 & 3.59 \\
Jam Kerja Nyaman & 100 & 1 & 5 & 3.51 \\
Perhatian Karyawan & 100 & 2 & 5 & 3.63 \\
Rasa Ketertarikan & 100 & 2 & 5.69 \\
Pemahaman Kebutuhan & 100 & $\mathbf{2}$ & $\mathbf{5}$ & $\mathbf{3 . 7 1}$ \\
\hline Empati & $\mathbf{1 0 0}$ & $\mathbf{2}$ & $\mathbf{5}$ & \\
\hline
\end{tabular}

Sumber: Data diolah

Tabel 4. Perbandingan Rerata Bank Syariah dan Bank Konvensional

\begin{tabular}{|ll|r|r|r|r|}
\hline & Jenis Bank yang Digunakan & \multicolumn{1}{c|}{ N } & \multicolumn{1}{c|}{ M ean } & Std. D eviation & Std. Error M ean \\
\hline \multirow{2}{*}{ Bukti Fisik } & Bank Konvensional & 100 & 3.93 & .555 & .056 \\
& Bank Syariah & 100 & 3.90 & .560 & .056 \\
Kehandalan & Bank Konvensional & 100 & 3.96 & .803 & .080 \\
Daya & Bank Syariah & 100 & 4.00 & .569 & .057 \\
Tanggap & Bank Konvensional & 100 & 3.92 & .692 & .069 \\
Jaminan Syariah & 100 & 4.04 & .680 & .068 \\
\multirow{2}{*}{ Empati } & Bank Konvensional & 100 & 3.95 & .575 & .058 \\
& Bank Syariah & 100 & 3.97 & .594 & .059 \\
& Bank Konvensional & 100 & 3.71 & .701 & .070 \\
& Bank Syariah & 100 & 3.87 & .646 & .065 \\
\hline
\end{tabular}

Sumber: Data diolah, 2015 


\section{Perbandingan Kualitas Layanan Bank Syariah Dan BankKonvensional (Pendekatan Model PBZ)}

H. Abdul Choliq \& Irwan Misbach

Berdasarkan Tabel 2 di atas, persepsi nasabah mengenai indikator kualitas layanan bank syariah yang paling baik adalah kemampuan bank dalam menangani masalah-masalah yang dihadapi nasabah dengan nilai rerata 4,19, kemudian diikuti dengan pemahaman bank terhadap kebutuhan nasabah dengan nilai rerata 4,12 , kesediaan karyawan bank untuk membantu nasabah dengan nilai rerata 4,02, kemampuan bank dalam memberikan layanan yang sesuai dengan yang dijanjikan dengan nilai rerata 4,01 dan kesopanan karyawan bank yang konsisten dengan nilai 4,0. Indikator lainnya masih belum maksimal dirasakan oleh nasabah karena masih berada di bawah nilai 4 .

Variabel yang paling baik berdasarkan persepsi nasabah adalah variabel daya tanggap dengan nilai rerata 4,04 meskipun indikator yang paling memberikan kepuasan adalah kemampuan bank dalam menangani masalah nasabah (indikator variabel kehandalan). Lebih lanjut, variabel kualitas layanan yang dipersepsikan nasabah mampu memberikan kepuasan adalah variabel kehandalan $(4,0)$ yang merupakan kemampuan bank untuk komitmen dan keunggulannya melayani nasabah dengan tepat dan terpercaya. Kemudian berturutturut adalah variabel jaminan dengan nilai rerata 3,97, bukti fisik dengan nilai rerata 3,90 dan empati dengan nilai rerata 3,87. Tabel 4.4 juga menunjukkan bahwa bukti fisik bank syariah belum mampu memberikan kepuasan yang memadai kepada nasabahnya.

\section{Kualitas Layanan Bank Konvensional}

Kualitas layanan bank konvensional dipersepsikan nasabahnya masi herada di bawah kategori yang bisa diandalkan. Ini bisa dilihat dalam Tabel 3 bahwa nilai rerata variabel yang dipersepsikan nasabah berturut-turut adalah variabel jaminan dengan rerata 3,95 kemudian diikuti dengan variabel bukti fisik dengan rerata 3,93, variabel daya tanggap dengan rerata 3,92, variabel kehandalan 3,90 dan variabel empati 3,71.
Berdasarkan Tabel 3di atas, kualitas layanan bank konvensional masih berada di bawah kategori baik. Meski demikian, beberapa indikatornya sudah dipersepsikan baik oleh nasabahnya yaitu bahwa pihak bank telah memperlihatkan ketertarikannya dalam memecahkan suatu masal ah yang dihadapi oleh nasabah dan memahami kebutuhan spesifik nasabah serta penampilan karyawan bank yang menarik.

\section{Perbandingan Kualitas Layanan Bank Syariah dan Bank Konvensional}

Bank Islam (syariah) merupakan bank yang secara operasional berbeda dengan bank konvensional. Dalam beberapa hal, bank syariah dan bank konvensional memiliki persamaan terutama dalam sisi teknis. Akan tetapi terdapat banyak perbedaan yang mendasar diantara keduanya yang menyangkut akad dan asek legalitas, lembaga penyelesaian sengketa, usaha yang dibiayai dan lingkungan kerja serta coorporate culture (Misbach, 2013: 66)

Dalam hal kualitas Iayanan, perbandingan antara bank syariah dan bank konvensional berdasarkan rerata masing-masing variabel yang diusulkan oleh Parasuraman etal. (1988) ditemukan perbedaan yang dapat dilihat dalam Tabel 4.

Berdasarkan Tabel 4, ditemukan bahwa rerata variabel bukti fisik bank konvensional lebih tinggi dibanding dengan bank syariah. $\mathrm{Hal}$ ini dimungkinkan karena bank konvensional telah lama beroperasi di Indonesia, khususnya di kota Makasar, sedang bank syariah mulai ada sejak berdirinya Bank Muamalat Indonesia tahun 1992 yang merupakan bank dengan sistem syariah.

Tabel di atas juga memperlihatkan bahwa selain variabel bukti fisik, bank syariah lebih baik dibandingkan dengan bank konvesional dalam hal variabel daya tanggap, kehandalan, jaminan dan empati. Bahkan variabel daya tanggap dan kehandalan dalam bank syariah dipersepsikan nasabah 
dalam kategori baik dan memuaskan. Hal ini sesuai dengan hasil penelitian Parasuraman et al. (1988) dan Misbach (2013) bahwa daya tanggap adalah keinginan atau kesiapan karyawan untuk menyediakan layanan merupakan variabel yang paling menentukan kualitas layanan. Ladhari et al. (2011) membandingkan persepsi kualitas layanan antara nasabah bank Kanada dan Tunisia dimana nasabah Kanada menerima kualitas Iayanan yang lebih tinggi dan menemukan bahwa dal am nasabah bank Tunisia, prediktor terpenting dalam kepuasan adalah daya tanggap dan kehandalan. Sedang, Shafie et al. (2004) yang mengukur persepsi pelanggan pada bank syariah di Malaysia menemukan bahwa dimensi daya tanggap merupakan atribut yang paling penting dalam kualitas layanan. Al Tamimi dan Al Amiri (2003, dalam Jabnoun \& Khalifa, 2005) menemukan bahwa kehandal an adalah dimensi paling penting dalam instrumen mereka, meskipun kehandalan yang ditemukan Jabnoun dan Khalifa (2005) menunjukkan bahwa menjadi signifikan ketika mempertimbangkan bank syariah dan bank konvensional secara bersamaan dan tidak signifikan ketika hanya mempertimbangkan bank syariah saja.

Dari data di atas, dapat disimpulkan bahwa kualitas layanan bank syariah masih lebih baik dibandingkan dengan kualitas layanan bank konvensional berdasarkan rerata kualitas layanan yang dipersepsikan nasabah. Namun untuk menjawab hipotesis perbedaan kualitas layanan bank syariah dan bank konvesional maka dilakukan uji T yang hasilnya nampak pada Tabel 5 di bawah ini.

Berdasarkan tabel di atas, ditemukan bahwa nilai t hitung dari semua variabel (bukti fisik = 0,381 ; kehandalan $=0,407$; daya tanggap $=1,237$; jaminan $=0,242$; dan empati 1,679 ) setelah dibandingkan dengan $t$ tabel $(2,382)$ yang nilainya lebih besar, maka hasil tersebut membuktikan bahwa hipotesis dalam penelitian ini ditolak. Demikian pula hasil uji dengan menggunakan kriteria Significant dimana nilai signifikansi masing-masing variabel (bukti fisik $=0,704$; kehandalan $=0,685$; daya tanggap $=0,218$; jaminan $=0,809$; dan empati $0,095)$ ternyata lebih besar dari $\alpha=0,05$ maka dapat diambil kesimpulan bahwa persepsi kualitas layanan tidak berbeda secara signifikan antara bank syariah dengan bank konvensional.

\section{KESIM PULAN DAN SARAN}

Berdasarkan hasil pembahasan pada bab sebelumnya dapat disimpulkan bahwa model kualitas layanan yang diperkenalkan Parasuraman et al . (1988) pada bank syariah masih dalam kategori baik, yaitu pada dimensi daya tanggap dan kehandalan, sedang dimensi lainnya sama dengan

Tabel 5. Hasil Uji T Bank Syariah dan Bank Konvensional

\begin{tabular}{|l|r|r|r|r|r|r|r|}
\hline & \multicolumn{1}{|c|}{$\begin{array}{c}\text { Levene's Test for } \\
\text { Equality of } \\
\text { Variances }\end{array}$} & \multicolumn{1}{|c|}{ t-test for Equality of M eans } \\
\cline { 2 - 8 } & \multicolumn{1}{|c|}{$\mathbf{F}$} & \multicolumn{1}{|c|}{ Sig. } & $\begin{array}{c}\text { t (nilai } \\
\text { absolut) }\end{array}$ & df & $\begin{array}{c}\text { Sig. } \\
\text { (2-tailed) }\end{array}$ & $\begin{array}{c}\text { M ean } \\
\text { Difference }\end{array}$ & $\begin{array}{c}\text { Std. Error } \\
\text { Difference }\end{array}$ \\
\hline Bukti Fisik & .172 & .678 & .381 & 198 & .704 & .030 & .079 \\
Kehandalan & 3.902 & .050 & -.407 & 198 & .685 & -.040 & .098 \\
Daya Tanggap & 1.137 & .288 & -1.237 & 198 & .218 & -.120 & .097 \\
Jaminan & .029 & .864 & -.242 & 198 & .809 & -.020 & .083 \\
Empati & 5.449 & .021 & -1.679 & 198 & .095 & -.160 & .095 \\
\hline
\end{tabular}

Sumber: Data diolah, 2015 


\section{Perbandingan Kualitas Layanan Bank Syariah Dan BankKonvensional (Pendekatan Model PBZ)}

H. Abdul Choliq \& Irwan Misbach

kualitas layanan bank konvensional yang masih berada di bawah kategori baik. Meski demikian, hasil penelitian ini membuktikan bahwa tidak terdapat perbedaan yang signifikan antara kualitas Iayanan bank syariah dengan kualitas Iayanan bank konvensional berdasarkan persepsi nasabah setelah mereka melakukan transaksi keuangan di bank tersebut.

Penelitian ini hanya mengukur persepsi nasabah mengenai kualitas layanan bank yang dirasakan oleh nasabah. Penelitian ini tidak mengukur persepsi nasabah mengenai kualitas layanan bank yang diharapkan oleh mereka, sehingga tidak dapat dibuktikan tingkat kepuasan mereka.

\section{DAFTAR PUSTAKA}

Amuaz. 2008. Perbedaan Karakteristik Bank Syariah dan Bank Konvensional, http:// wartawarga. gunadarma.ac.id/ 2010/ 06/ perbedaan-banksyariah-dan-bank-konvensional-2/

Asubonteng, P., McCleary, K.J. dan Swan, J.E. (1996). SERVQUAL Revisited: A Critical Review Of Service Quality. Journal of Services M arketing, 10 (6): 62-81.

Barokah, Robby. 2009. Makalah BASYARNAS, http:/ / robbybarokah. blogspot.com/ 2009/ 06/ makalahbasyarnas.html?m=1

Buttle, F. 1994. SERVQUAL: Review, Critique, Research Agenda. European Journal of M arketing, 30: 8-32

Cronin, J.J., Taylor, S.A. 1992. Measuring ServiceQuality: A Reexamination and Extension. Journal of $\mathrm{M}$ arketing 56: 55-68.

Gefan, D. 2002. Reflections on the Dimensions of Trust and Trustworthiness among Online Consumers. The DATA BASE for Advances in Information Systems, 333: 38-53.

Grönroos, C. 1984. A Service Quality Model and Its Marketing Implication. European Journal of $M$ arketing, 18 (4): $36-44$

Grönroos, C. 2001. The Perceived Service Quality Concept - A Mistake. M anaging Service Q uality, 11(3): 150-152.
H ossain, M. and Leo, S. 2009. Customer Perception on Service Quality in Retail Banking in Middle East: The Case of Qatar, International Journal of Islamic and $M$ iddle Eastern Finance and M anagement, 2 (4): 338-350

Irawan, M. 2010. Pengaruh Dimensi Kualitas Pelayanan Terhadap Persepsi Dan Kepuasan Pengguna Jasa Lembaga Keuangan Syariah. http:// mul 1rawan.wordpress.com/ category/ pengaruhdimensi-kualitas-pel ayanan-terhadap-persepsidan-kepuasan-pengguna-jasa-lembagakeuangan-syariah/

Irfan, S.M. dan Ijaz, A. 2011. Comparison of ServiceQuality Between PrivateAnd Public Hospital s: Empirical Evidences From Pakistan. Journal of Q uality and Technology M anagement. 7 (1): 122.

Ismail. 2011. Perbankan Syariah, Jakarta: Kencana Prenada Media Group

Jabnoun, N. and Khalifa, A. 2005. A Customized Measure Of Service Qual ity In The UA E, M anaging Service Q uality, 15 (4): 374-388

Karim, Adiwarman. 2004. Bank Islam (A nalisis Fiqih dan Keuangan), Jakarta: Raja Grafindo Persada.

Kotler, Philip. 1997. Marketing Management. New Jersey: Prentice-Hall.Inc

Ladhari, R., Ladhari, I and Morales, M. 2011. Bank Service Quality: Comparing Canadian and Tunisian Customer Perceptions, International Journal of Bank M arketing, 29 (3): 224-246

Mengi, Pooja. 2009. Customer Satisfaction with Service Quality: An Empirical Study of Public and Private Sector Banks.. Institute of Chartered Financial Analysts of India (Hyderabad). The ICFA I Journal of $M$ anagement Research. 8 (9): 7-18

Misbach, Irwan. 2012. Kualitas Layanan Bank Syariah. Alauddin University Press. Makassar.

. 2013. Bank Syariah: Kualitas Layanan, Kepuasan dan Kepercayaan. Alauddin University Press. Makassar.

Murni, Asfia. 2009. Ekonomika M akro, Bandung: Refika Aditama

Nimit, Chowdhary dan Monika, Prakash. 2007. Prioritizing Service Quality Dimensions. M anaging Service Quality, 17(5): 493-509. 
Parasuraman, A., Berry, L. and Zeithaml, W. 1985. A Conceptual Model of Service Quality and its Implications for Future Research", Journal of M ar keting 49: 41-50.

Parasuraman, A., Berry, L. and Zeithaml, W. 1988. SERVQUAL: a Multiple Item Scale for Measuring Consumer Perceptions of Service Quality, Journal of Retailing, 64 (1): 2-40.

Parasuraman, A., Berry, L. and Zeithaml, W. 1990. Delivering Quality Service. The Free Press, New York.

Rachdian. 2011. Perbedaan A ntara Bank Syariah Dan Bank Konvensional, http:/ / databaseartikel.com/ ekonomi/ perbankan-ekonomi/ 20118034perbedaan-antara-bank-syariah-dan-bankkonvensional.html

Samson, Parker (1994). Service Quality: The Gap in the Australian Consulting Engineering Industry. International Journal of Quality \& Reliability $M$ anage ment, 11 (7): 60-76.
Shafie, S., Azmi, W.N.W., Haron, S. 2004. Adopting And Measuring Customer Service Quality In Islamic Banks: A Case Study Of Bank Islam Malaysia Berhad, Journal of M uamalat and Islamic Finance Research, 1 (1): 1-12

Wirat, M. S. 2007. A nalisis Pengaruh Kinerja Pelayanan Terhadap Kepuasan dan Loyalitas Pelanggan Industrial. Disertasi PPs FE UB

Wisniewski, M. (2001). Using SERVQUAL to A ssess Customer Satisfaction with Public Sector Services. M anaging Service Quality, 11 (6): 380-388.

Yavas U., Bankenstein, M. and Stuhldreier, U. 2004. Re lationships Between Service Quality and Behavioral Outcomes, The International Journal of Bank M arketing, 22 (2): 144-157 